DOI https://doi.org/10.30525/978-9934-26-040-7-45

\title{
ОСОБЛИВОСТІ ГРОМАДСЬКОГО КОНТРОЛЮ У СФЕРІ ВИЩОЇ ОСВІТИ В УКРАЇНІ
}

\author{
Редіна П. В. \\ аспірант кафедри адміністративного права \\ Національного юридичного університету імені Ярослава Мудрого \\ м. Харків, Украӥна
}

Важливою складовою системи управління у сфері вищої освіти виступає контрольна діяльність, яка спрямована на забезпечення ефективного функціонування закладів вищої освіти під час здійснення ними своїх функцій в освітній сфері. Серед гарантій реалізації права на освіту можна виділити розділ VIII Закону України «Про освіту» «Управління та контроль у сфері освіти» та розділ XIV Закону України «Про вищу освіту» - «Контроль у сфері вищої освіти», присвячені державному управлінню у цій сфері.

Дослідження питання контролю у сфері вищої освіти доцільно почати із уточнення змісту поняття «контроль». Термін «контроль» походить від латинського «contra role» (від якого утворилося французьке слово «controle»), що означає співставлення або протиставлення. Згідно з великим тлумачним словником сучасної української мови, контроль: 1) перевірка відповідності контрольованого об'єкта встановленим вимогам; 2) перевірка, облік діяльності кого-, чого-небудь, нагляд за кимсь, чимось; 3) установа чи організація, що здійснює нагляд за ким, чим-небудь або перевіряе його. На сторінках Великої юридичної енциклопедії (Харків, 2021, Т. 5. С. 445) контроль визначається як поняття, яке у законодавстві та в інших нормативноправових актах етимологічно означає перевірку, виконання, дотримання чи досягнення, інспектування визначених завдань та отриманих результатів у будь-яких сферах державної діяльності та функціонуванні місцевого самоврядування.

Громадський контроль $є$ одним із видів соціального контролю, який здійснюється об'єднаннями громадян та самими громадянами i $\epsilon$ важливою формою реалізації демократії і способом залучення населення до управління суспільством та державою. Громадський контроль, це також одна з функцій громадянського суспільства, проявом якої $\epsilon$ публічна перевірка діяльності органів влади з боку громадян та їх 
об'єднань на відповідність цілей, які влада проголошує, спрямована на коригування як цієї діяльності, так і самих цілей. У свою чергу, його метою є налагодження дієвого та результативного діалогу між органами влади та суспільством на всіх етапах процесу прийняття рішень. Громадський контроль, що проводиться окремими інститутами громадянського суспільства, на сьогодні є невід'ємною складовою механізму демократичної, правової держави. Все вищенаведене повною мірою відноситься і до контролю у сфері вищої освіти.

Відповідно до ст. 78 Закону України «Про вищу освіту» громадський контроль у сфері вищої освіти є правом суспільства та окремих громадян, працівників у сфері вищої освіти, осіб, які навчаються, органів громадського самоврядування, професійних спілок, організацій роботодавців та їх об'єднань, громадських організацій отримувати у встановленому законодавством порядку доступ до інформації на всіх етапах прийняття рішень у сфері вищої освіти і науки, вносити пропозиції та зауваження до них, погоджувати прийняття визначених законом рішень. Він здійснюється громадськими об'єднаннями та окремими громадянами на принципах відкритості і прозорості.

При Міністерстві освіти і науки України діє тимчасово-дорадчий орган - Громадська рада, який утворений для сприяння участі громадськості у формуванні та реалізації державної політики, ефективної взаємодії Міністерства освіти і науки України (далі - MOH) 3 інститутами громадянського суспільства, здійснення громадського контролю за діяльністю МОН України, врахування побажання громадськості при формуванні та реалізації державної політики у сфері компетенції МОН. Одним із основних завдань Громадської ради $\epsilon$ здійснення громадського контролю за діяльністю МОН. Громадська рада функціонує на засадах самоврядності та відповідно до основних завдань здійснює громадський контроль за врахуванням МОН пропозицій та зауважень громадськості, а також дотриманям ним нормативно-правових актів, спрямованих на запобігання та протидію корупції.

До одних 3 найбільш активних суб'єктів громадського контролю традиційно відносять професійні спілки. Вважається, що вони є тим осередком, в якому зосереджується сила суспільного контролю. Юридичною основою здійснення професійними спілками громадського контролю є положення Закону України «Про професійні спілки, їх права та гарантії діяльності», згідно з якими профспілки здійснюють громадський контроль за виплатою заробітної плати, додержанням законодавства про працю та про охорону праці, створенням безпечних i нешкідливих умов праці, належних виробничих та санітарно-побутових 180 
умов, забезпеченням працівників спецодягом, спецвзуттям, іншими засобами індивідуального та колективного захисту.

У Законі України «Про вищу освіту» професійні спілки визначені суб'єктами громадського контролю у сфері вищої освіти. Окрім того, Законом передбачено, що керівники виборних органів первинних профспілкових організацій працівників та первинних профспілкових організацій студентів та аспірантів вищих навчальних закладів входять до складу вченої ради ЗВО.

Законом встановлено порядок консультацій з громадськістю на загальнодержавному рівні. Ст. 12 покладає на Кабінет Міністрів України зобов'язання забезпечувати широку участь незалежних експертів і представників громадськості, роботодавців та осіб, які навчаються у закладах вищої освіти, у підготовці та прийнятті проектів нормативно-правових актів та інших рішень, що стосуються регулювання взаємодії складових системи вищої освіти та іії функціонування в цілому. Ст. 13 передбачає функціонування дорадчої установи з питань розробки стандартів освіти - науково-методичної ради у складі урядовців, роботодавців, міжнародних експертів, представників вищих навчальних закладів, наукових установ, професійних асоціацій.

В ст. 36 прописано механізми громадського контролю в межах самих 3ВО. Ці функції покладено на збори колективу (орган громадського самоврядування) та на вчену раду (колегіальний орган управління 3ВО). Загальні збори (конференція) трудового колективу, включаючи виборних представників з числа студентів (курсантів) $\epsilon$ вищим колегіальним органом громадського самоврядування закладу вищої освіти. На зборах погоджується статут ЗВО, заслуховується звіт керівника та розглядаються питання про його дострокове звільнення, затверджується внутрішній розпорядок тощо. Вчена рада, яка формується з керівників різного рівня, голів самоврядування, виборних представників студентства, наділена реальними повноваженнями щодо призначення на основні посади, затвердження освітніх програм, ухвалення фінансових планів та інше. Органом громадського самоврядування навчально-наукового інституту (факультету) $€$ збори (конференція) трудового колективу навчально-наукового інституту (факультету), включаючи виборних представників з числа осіб, які навчаються у закладі вищої освіти. Невід'ємною частиною громадського самоврядування є студентське самоврядування, вищим органом якого $є$ загальні збори (конференція) студентів (курсантів).

Зазначимо також і те, що рішення та діяльність у сфері вищої освіти, крім інформації з обмеженим доступом, є відкритими. 3 метою забезпечення прозорості та відкритості діяльності ЗВО обов'язковому 
оприлюдненню на офіційних веб-сайтах та у засобах масової інформації, на інформаційних стендах та в будь-який інший спосіб підлягає інформація про процедури та результати прийняття рішень i провадження діяльності у сфері вищої освіти. Також обов'язковим $є$ громадське обговорення бюджету ЗВО, його видатки та доходи, стан майна закладу вищої освіти та порядок його використання.

DOI https://doi.org/10.30525/978-9934-26-040-7-46

\title{
ПИТАННЯ ОПТИМІЗАЦІЇ СУБ'ЄКТІВ ВЛАДНИХ ПОВНОВАЖЕНЬ У СФЕРІ ДЕРЖАВНОЇ РЕССТРАЦІЇ
}

\author{
Розгон О. Г. \\ кандидат юридичних наук, \\ доиент кафедри адміністративного права, \\ процесу та адміністративної діяльності \\ Дніпропетровського державного університету внутрішніх справ \\ м. Дніпро, Україна
}

Сьогодні Україною приймається низка заходів, спрямованих на удосконалення процедур державної реєстрації. Зокрема, такі зміни стосуються державної реєстрації речових прав на нерухоме майно та їх обтяжень. Як зазначає С. Регелюк, ще у листопаді 2020 року, у Верховній Раді України було зареєстровано законопроект за № 4338 «Про внесення змін до деяких законів України у зв'язку з впорядкуванням діяльності у сфері державної реєстрації речових прав на нерухоме майно та їх обтяжень та у сфері державної реєстрації юридичних осіб, фізичних осіб - підприємців та громадських формувань», спрямований на покращення надійності та безпеки реєстрів підприємств та нерухомості [1].

Необхідно відмітити, що поряд із удосконаленням процедури державної реєстрації речових прав на нерухоме майно та їх обтяжень, адміністративно-правова протидія правопорушенням у цій сфері також вимагає перегляду та впровадження новацій. Значною мірою це стосується суб'єктів адміністративно-правової протидії таким правопорушенням.

Зауважимо, що відповідно до статті 6 Закону України «Про державну реєстрацію речових прав на нерухоме майно та їх обтяжень» від 01.07.2004 № 1952-IV, систему державної реєстрації прав становлять: а) Міністерство юстиції України та його територіальні органи; 182 